\title{
Requiem for Baikal as a warning
}

\author{
Valentin Tkachev ${ }^{1}$ and Yurii Dagaev ${ }^{*}$ \\ ${ }^{1}$ Moscow State University of Civil Engineering (MGSU), 129337, Yaroslavl sh. 26, Moscow, Russia
}

\begin{abstract}
Baikal, the "sacred sea", a unique natural phenomenon with fresh water resources for the entire planet, is threatened with turning into a muddy puddle.In recent years, the shores of Lake Baikal have become more and more accessible for exploration by tourists from the center of Russia and abroad.Tourists and entrepreneurs from China, who compensate for the economic vacuum in Siberia, providing the local population with work in the absence of a state system of economic integration of the region into the general economic structure of the country, are especially actively populating the south of Baikal.Travel companies that have reached Lake Baikal provide guests with minimal comfort in primitive coastal houses and do not care about neutralizing household waste flowing into the lake.The most dangerous source of pollution is the pools with poisonous sludge located on the very shore of the lake, which were left after the closure of the Baikal Pulp and Paper Mill in 2013. In the near future they can be washed away by mountain mudflows.It is necessary that the central and local authorities, when creating the programs to prevent the destruction of Lake Baikal, should be guided by the simplest form of survival developed by nature to extinguish the phenomena that threaten its existence. This is the concept of METABOLISM, which means a system of living in the regime of the circulation of substances, the real preservation of the ecological balance even by tough measures of educating the consciousness of a person.
\end{abstract}

\section{Introduction}

The distance in half of the Eurasian continent, dividing European Russia, where the public worldview and paradigms of the future are being formed, poorly reaching Siberia, and Baikal, an object of national pride, for a long time left a ghostly sense of value, a permanent inexhaustible resource that did not require maintenance costs. As in the case of the Far North and Eastern Siberia, which appeared for the "metropolis" as a storehouse of natural resources, which no one else has. It seemed that diamonds and gold of Yakutia, oil and gas, forests and hunting grounds, the purest water of Lake Baikal, which stores a fifth of the world's fresh surface water reserves in the natural refrigerator of permafrost, would always exist unchanged as a granary of the Motherland.

However, modern economic thinking has matured to understanding the immediate integration of the East Siberian region into the country's economic system, raising the civilizational level of its development, creating a network of industrial centers and highways, settlements that extinguish the demographic vacuum of a huge territory.

\footnotetext{
${ }^{*}$ Corresponding author: dagaev.yua92@gmail.com
} 
Archaic forms of involving undeveloped territories in the economic turnover are clearly unsuitable, mainly because they take into account only consumer interests. It is equally archaic to entrust the development of the territory to predators.

The preservation of the ecological balance, concern for the restoration of resources, investment in the rehabilitation of disturbed natural systems were not specifically planned.

Positive action plans were developed in the most general terms and in the subjunctive mood.

The termination of the destructive activities of the Baikal PPM did not end its impact on the environment - more than 6.5 million tons of toxic waste on the lake shore are still awaiting liquidation. But several contractors have already refused this work [1].

The stage of Baikal's life as an "untouched natural territory" has come to an end. Numerous holiday centers, tourist camps, summer cottages, and shelters of local residents spontaneously appear on its shores, the habitation of which is far from the civilized regimes of preserving the unique and vulnerable ecological system of Lake Baikal. Waste is added to the disturbance of the landscape.

The 1999 Federal Law "On the Protection of Lake Baikal" only in the most general terms introduces restrictions on the construction of new facilities in the BNT (Baikal Natural Territory) zone and the reconstruction of existing ones, shifting to local administrative bodies the specific regulation of the activity of those wishing to settle near the "sacred sea", i.e. in reality, this process has been left on its own, because the concepts of the legal basis of land use in the region have not even been edited.

The pandemic of the central regions of Russia and the restriction of foreign tourism stimulate the intensification of human flows to the recreationally attractive and safe points of Siberia. Baikal is becoming a center of increased tourist interest not only for Russians, but also for foreign guests [2].

In any case, it is necessary to take into account the planetary significance of Lake Baikal as a reservoir of clean water, and the uncontrolled settlement of its shores by people, in whose minds there is no understanding of the culture of waste-free living in the natural environment, already now, even on the eve of the "invasion" of tourists, negatively affects the health of the lake.

Meanwhile, the inclusion of Lake Baikal in the general system of nature management is inevitable, including due to economic reasons [3-5].

And the question arises in what area to envisage the further development of the Baikal territories, without limiting their population and preserving, on the other hand, its natural ecology.

There are three areas to choose from, not excluding their interaction:

Provide the development of the territory, but under strict control of the implementation of the Code of the habitat, which has yet to be created.

Develop a plan for the placement of official recreational facilities in attractive and accessible places away from the coast (preferably on the basis of existing tourist complexes), with the organization of infrastructure, transport, efficient treatment facilities.

Exclude all objects that are not related to the systems for maintaining the required sanitary and ecological level of the lake and its shores from the development plans. Possible recreational facilities should not be located in the BNT zone, and the interests of tourists should be addressed in excursion mode.

Of course, the territory must be cleaned from existing sources of pollution. Baikal should be presented to humanity in a rehabilitated form.

Production at the Baikal PPM has been stopped. However, it is still a particularly dangerous object, on the territory of which poisonous waste is stored near the coast, a heating plant operates, and nearby there is the Gusinoozerskaya GRES, the Selenginsky pulp and cardboard mill, various production facilities of Irkutsk. Ulan-Ude dumps 200 thousand cubic 
meters of industrial waste into the Selenga per day, and the eggs of fish that go to spawn at the mouth of the river almost completely die from poisoning [6].

There is also a real danger of mudflows descending from the mountains, which will wash away all the accumulated poisons into the lake. The Baikal Pulp and Paper Mill was "successfully" located at the foot of these mountains. But this is also a seismic zone.

Resolutions on decisive measures to save Lake Baikal remain on paper, and the billions allocated for this work, they say, have settled in banks.

But everything is extremely simple. Enterprises that emit hazardous and normal wastes should INITIALLY have treatment facilities equivalent in power, and where the technological carrier is water, the problem is solved even easier - by closed water circulation cycles.

The entire circulation of the planet's matter is decided on the principles of METABOLISM: the inflow is equal to the outflow. Does anyone from the bankrupt Institute of Toxic Examination know about these fundamentals of biogeocoenosis?

It seems that the impending ecological catastrophe scares only in theory, as a certain inevitability of the end of life with the total end of the world.

The same problem of neglecting metabolism is the spontaneous development of the banks, whose residents, most often temporary workers, dump mountains of garbage and drain sewage downhill.

While the flows of tourists from the west are just gathering together, the shores of Lake Baikal are populated by the Chinese, and it is closer and cheaper for them to travel here.

The obvious need to build a bridge to Olkhon Island is hampered by local residents fearing an unlimited influx of tourists, although, on the other hand, all life here is focused on tourist service.

The land along the southern end of the lake has been sold to Chinese entrepreneurs who are building hotels, shelters, shops, household businesses, country houses, forming entire ethnic villages. It has not yet come to the construction of infrastructure, since this is a municipal scale. There is nowhere to remove waste from septic tanks and sedimentation tanks.

The distribution hub of tourists is Listvyanka, where routes along the lake begin. There are a lot of Chinese hotels, buses bringing tourists in and out, signs in Chinese [7].

Spirogyra and Elodea algae thrive on the waste seeping into the lake, which, dying off, form bottom cemeteries of organic matter, and on the surface - pancakes of blue-green algae $[8]$.

The environmental prosecutor's office is powerless. Even national parks are not protected by law from intrusion by unauthorized land users who are illegally licensed by the authorities.

The government regularly changes contractors for the disposal of BPPM waste, which do not meet the examination requirements.

Understanding the concept of metabolism, although efforts are being made to dispose, recycle, and neutralize waste, is still mainly on paper.

Meanwhile, this is a planetary problem, which especially affect Lake Baikal, the purity of its water. Natural laws of transformations are projected on human activity.

The concept of metabolism originated in Japan as a result of the synthesis of the ancient religion of Zen Buddhism and the life circumstances of an island country that exists on a narrow strip of coast between the sea and the mountains, stimulating respect for the land of habitation.

The ideologist of metabolism in architecture - K. Kikutake - conceived it as an alternative to functionalism back in the middle of the 20th century. The idea was picked up and developed by the outstanding architect of Japan - K. Tange, as well as K. Kurokawa [9, 10]. And it seems that the concept of metabolism is the only key to solving all the problems of Lake Baikal. 
And it is necessary to immediately mobilize measures, almost military ones, to prevent a catastrophe at the ruins of the BPPM or prevent the removal of toxic sludge from storage pools beyond the limits of possible discharge into Baikal.

The second problem: the direction of tourist flows.

The most realistic way is to protect Baikal from "household" pollution by organizing a cultural civilized tourist business, literate from the point of view of metabolism. Then the construction and reconstruction of tourist hotels will not create another cancerous tumor around the lake. There is a lot of work to be done on the education of the inhabitants' consciousness, the culture of the region's development, and the provision of the necessary capacity of the treatment systems.

Note that the concept of metabolism includes not only the equivalent exchange of matter, but also systemic growth similar to the development of a living organism.

\section{Materials and methods of research}

The problem of Lake Baikal, brought up for discussion, is bipolar:

on the one hand, the alarming state and threats of an exogenous catastrophe from pollution are obvious, the focus of which is the environmental hazard from the BPPM, as well as household pollution of recreational areas, their irresponsible exploitation by tourists and the local population, on the other hand, the need to include Baikal in the country's overall socioeconomic system, integration of the potential of Siberia into a single economic structure of the country, sparing realization of tourist interest in the lake and its surroundings.

The simultaneous solution of both problems is possible only with the competent implementation of the concept of metabolism, the closure of the trophic chains so that the emissions of vital activity are compensated by adequate measures to restore the natural balance, or at least the alienation of the built environment from the natural landscape, which is achieved by preventive work on the civic consciousness of people arriving on vacation to the lake with the simultaneous development of infrastructures of civilized habitation in nature protection zones.

This will, of course, be a very costly system for the exploitation of the region, but we will not condemn ourselves to the curses of our descendants, depriving them of not only pure water...

Lack of technical, administrative, and financial mobilization, organizational sluggishness and the inability to take emergency measures to save Lake Baikal by Russian efforts will force resort to qualified assistance from the international community, despite the strained relations with "partners". It will be a shame!

And this year's snowy winter brings the threat of mudflows down the mountains surrounding the BPPM. And all the troubles will disappear by themselves!

Objective monitoring data, alarming publications of eyewitnesses to the state of the former plant are supplemented by the threat of pollution of the lake shores to the north of the main centers of settlements - by the intensification of tourist flows from the west, Russian and foreign ones.

The contamination and pollution of the traditional for Russians places of summer vacations on the Black and Mediterranean Seas, Indochina will reorient interests to the still undeveloped, wild places of Siberia.

The expected onslaught of tourist "hordes" on Baikal, Kamchatka, and the Far North promises to turn them into the same trampled territories strewn with garbage, like the southern resorts. The media is actively stirring up interest in Lake Baikal with advertisements of travel agencies, promising a full-fledged, inexpensive vacation among the amazing nature. 
The low level of ecological consciousness of the campers attacking nature forces them to go to special educational events, the publication of memoranda of behavior, impressive punishments for violating the rules of civilized life.

Note that for a person of internal culture, such restrictions on behavior are not a burden. For others, let the trip to Baikal become a school of behavior of a cultured person, and not an adrenaline rush of a savage from the stone jungle who escaped into nature.

Thus, the methodological framework of the study is based on a purposeful orientation towards a radical change in the everyday paradigm of the development of Lake Baikal, as well as the entire Eastern Siberia, towards a civilized approach based on the concept of metabolism, but not symbiosis. Humanity has already stepped over this phase of awareness of the unity of coexistence. Nowadays, the artificial habitat no longer painlessly comes into contact with living nature. The best mode of their neighborhood will be the careful maintenance of the boundary contacts of the two systems.

\section{Research results}

The main geographic parameters of Lake Baikal:

The arc of the lake stretches from south to north for $630 \mathrm{~km}$.

The width of the lake ranges from 30 to $80 \mathrm{~km}$.

The volume of water is 23 thousand $\mathrm{km} 3$.

The inflow-outflow balance is about $60 \mathrm{~km} 3$ per year.

The maximum depth (near Olkhon Island) is about $1640 \mathrm{~m}$. The western coast has a steep slope, the shelf of the left bank is gentle, it is better warmed by the sun.

The Baikal rift is expanding at a rate of $2 \mathrm{~cm} /$ year.

The water's edge is $465 \mathrm{~m}$ above the ocean level (Baikal will remain in case of warming and flooding of the continents).

High seismicity - from 5-6 to 10 points on the Richter scale.

The number of tributaries (including the largest and most polluted - Selenga) is about 336, some dry up in summer.

There are strong winds (mainly in the south), hurricanes with wind speeds up to $40 \mathrm{~m} / \mathrm{s}$ and wave heights up to $6 \mathrm{~m}$.

The number of sunny days is on average 50 per year, in the Listvyanka area - up to 100 .

The warmest place is Peschanaya Bay. Here, the average annual temperature is 0.4 degrees.

Freezing up in December-January, breaking up of ice in May. Ice thickness - up to 100 $\mathrm{cm}$.

In spring, ice is squeezed $20-30 \mathrm{~m}$ ashore, pushing ships and destroying berths.

The water is transparent, the light of the sun penetrates to a depth of $500 \mathrm{~m}$. [11, 12].

The traditional places of Baikal settlement are the western coast, where high rocky outcrops are interspersed with gentle valleys with a pebble landscape. Taiga exists on the northern part of the island, steppe arid territories - at latitudes of Olkhon Island. Under the condition of a civilized coastal development regime, the preferred places for the location of recreational facilities correspond to traditional, with a gentle relief, at a distance from the water (where it is colder), with a protective barrier of mountains, in the presence of springs, including hot ones: Obuteikha, Skriper, Aya, Ayaya, Peschanaya, Babushka bays, springs of Goryachinsk, Khakusov, capes Kadilny, Kotelnikovsky, and Sagan-Khushun.

There are caves on Lake Baikal: on Olkhon, Bolshoy Ushkany Island, Cape Ludar ancient people lived in them, sometimes fishermen take refuge here.

Olkhon Island is separated from the coast, and connection is carried out by a low-capacity ferry. A suspended bridge can be installed, since regular supports do not withstand the pressure of ice. 
What is the picture of the settlement of the shores of Lake Baikal with recreational structures of primitive architecture and limited functions today?

Provision of living quarters for visiting by enterprising tenants who have built wooden houses with ascetic comfort. There are several tourist centers and boarding houses with a more organized structure and service (Fig. 1).

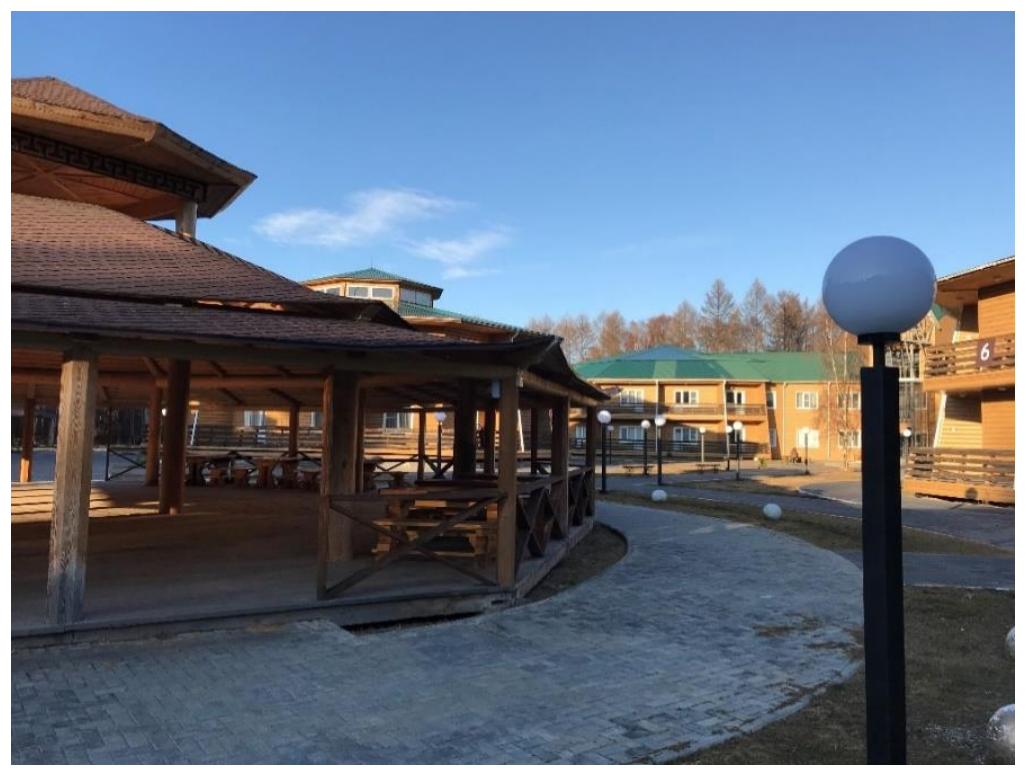

Fig. 1. Tourist complex "Park Sagaan Morin", Sukhaya village. Photo by the author.

More than a dozen holiday centers of various categories are located on Olkhon. They have canteens, cafes, shops, first-aid posts, and souvenir shops. The indigenous population is engaged in tourist services and suffers from an oversupply or shortage of them.

Relatively capital buildings of hotels, recreation centers, camping sites were built in Listvyanka (which is considered the tourist capital of Lake Baikal), Baikalsk, Severobaikalsk, Goryachinsk, Sakhyurt, Bolshoye Goloustnoye (opposite Peschanaya Bay) (Fig. 2).

They are located almost on the very shore. The common image for all is provincial design and living conditions based mainly on wooden architecture.

But the attention of guests is focused on local landscapes complemented by exotic services: acupuncture, hirudotherapy, herbal medicine, massages, therapeutic mud, mineralrich waters. Unsuitable living conditions is compensated by the awareness of being on Lake Baikal!

"Aborigines" (you cannot name it otherwise) offer various services for the development of the lake and its surroundings. This is a typical seasonal business for the local population in the resort areas.

There is also an official service, for example, with the organization of water or walking "ontological" excursions. 


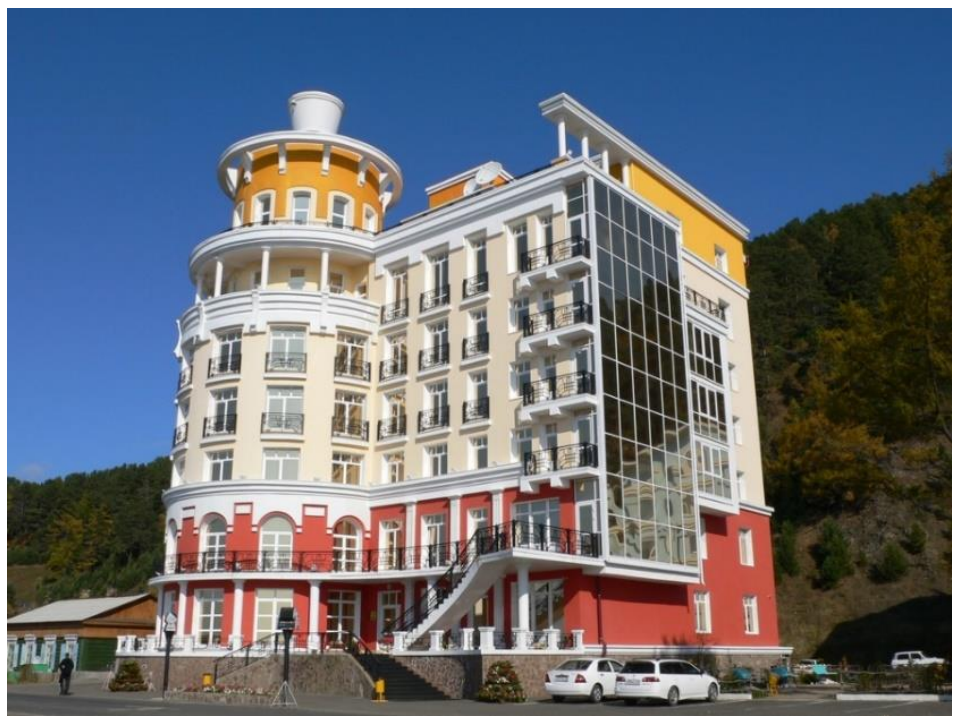

Fig. 2. Hotel "Mayak", Listvyanka settlement. Source: http://www.mirbaikal.com/accomodation/accomodation_other/

Some centers of tourist service have existed for a long time and are waiting for both architectural reconstruction and a mandatory program for solving metabolism - this is about the Goryachinsky resort, hotels in Listvyanka, on Olkhon, in the Kurkutsky Bay, the Baikal Dunes recreation center near Peschanaya Bay (Fig. 3).

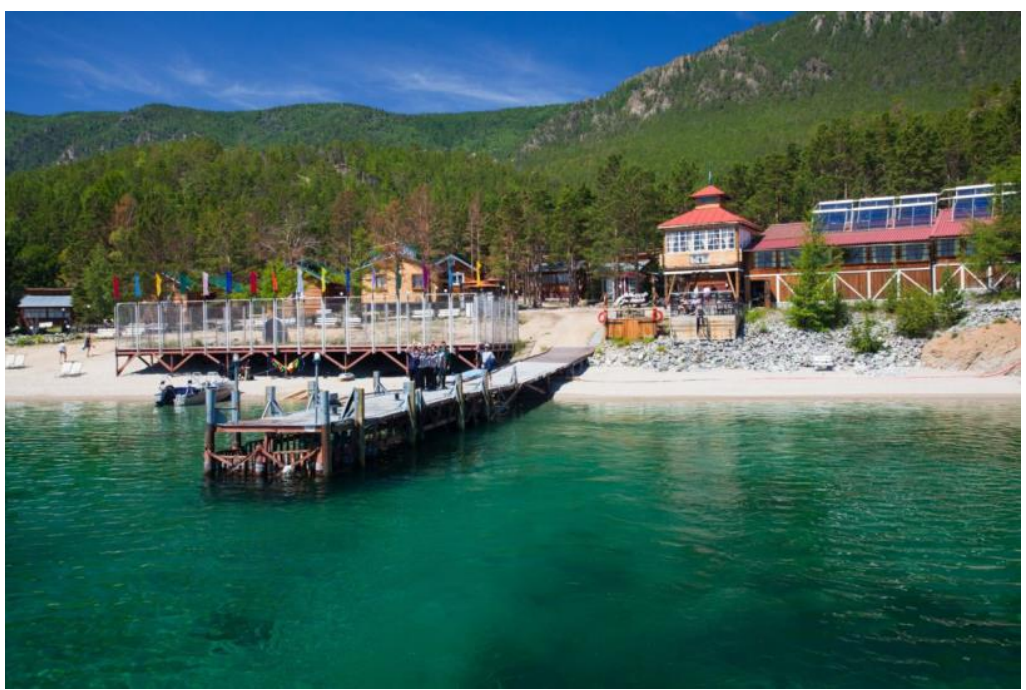

Fig. 3. Recreation center "Baikal Dunes" Irkutsk region. Source: https://gobaikal.online/otdyh-nabaykale/

Hotel "Zolotaya Rybka" on Cape Kotelnikovsky near Severobaikalsk can serve as the standard of a civilized functional and architectural solution based on hot springs (Fig. 4). 


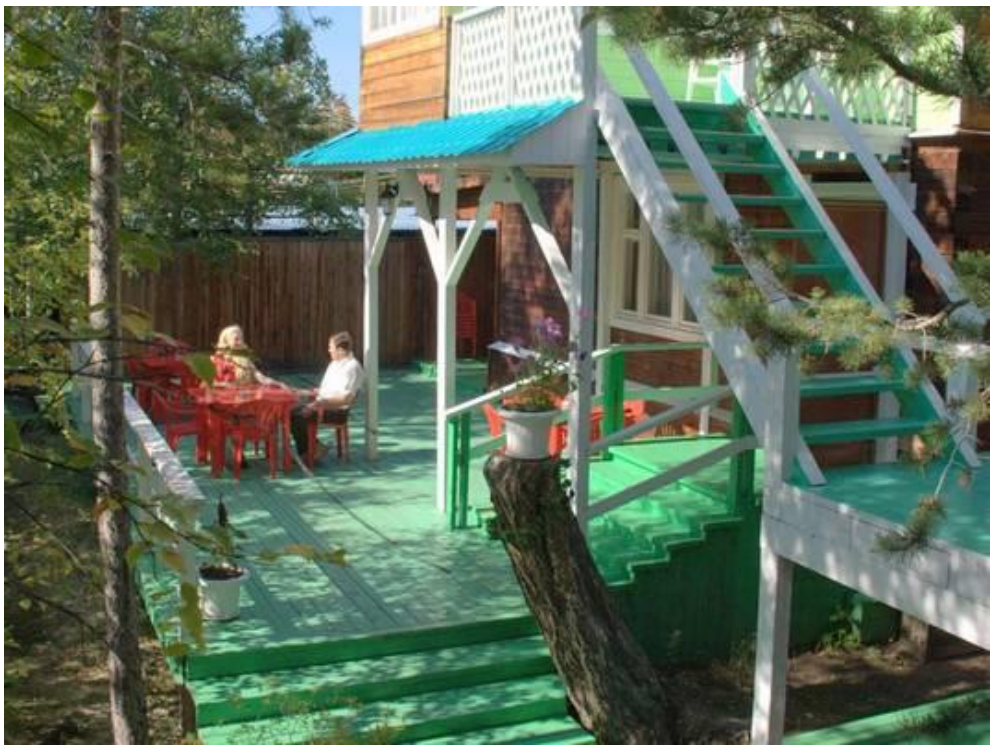

Fig. 4. Hotel "Zolotaya Rybka", Severobaikalsk. Source: https://baikalhotels.com/turbazy/otelzolotaya-rybka/

Most of the resorts on the western coast of Lake Baikal are inaccessible from land. They are closed in winter and organize tours in summer. For example, the base "Baikal Dunes" provide walking tours to the Peschanaya, Babushka, Akademicheskaya bays, as well as water tours.

Fascinated by Baikal itself, tourists forgive some unsuitable living conditions in shelters, bases, and camping sites.

The general impression of the whole complex of the Baikal tourism "industry": location, architecture, and service are in the tradition of the XX century. Perhaps this archaic plus relatively untouched by civilization landscapes are the attraction of the Baikal tourist bases, guest houses, holiday centers.

The most popular and developed transport locations have already been developed and can serve as a support base for programming radical reconstructive measures in this area, solving the problems of habitat culture and economy, not counting, of course, on turning the region into a kind of Monte Carlo.

So far, behind the external well-being of these centers of tourism development, there is a lack of concern about sanitation. The low density of distribution of recreational points does not conceal the dangers of total pollution, but this is only for the time being...

Active advertising accompanied by positive feedback from guests presents the Baikal tourism industry at its best.

The offered range of services and entertainment: contemplation of landscapes, obtaining historical and ethnographic information, walking and water tours, winter and summer sports, work in art centers, simply psychological relief, treatment and exotic wellness procedures.

In the future, however, under the connivance of the local administration, the chain of settlements around Lake Baikal is getting denser, and sooner or later the problems of sanitation of the landscape and water will come to the surface. For local people, trouble will come imperceptibly, if not to take into account the impending threat of a sudden mudflow catastrophe.

The Chinese actively populate Olkhon, not allowing Russian tourists there, and also arrange settlements in Listvyanka and other places in the southern end of the lake. 
But here's the paradox: the pandemic has stopped the influx of tourists, and the Olkhon economy is suffering losses, the local population is losing their jobs. That is, the Chinese are making a stable contribution to the region's economy. They came up with an initiative to build a plant for bottling Baikal water and a water pipeline to China. The price of Baikal water is \$2/liter. Is it profitable? Yes, especially since all Baikal water is uselessly carried out by the Angara into the Arctic Ocean. Russia already has a tradition of selling oil, gas, timber, and water can be sold as long as it is still clean. The project of a plant for bottling Baikal water has been approved by the state expertise and will be launched in 2021 .

Local residents, although they expect an increase in the number of jobs at such factories, fear that in 5-10 years Baikal will turn into one of the provinces of China - the information that Baikal belonged to China in ancient times repeatedly appears in the Chinese media [13].

The urbanization of the south of Baikal is accompanied by announcements in Chinese about the sale of plots in Listvyanka, often to Russian intermediaries. Here, by the way, the Chinese - Russian citizens - have been living for a long time.

Russian Siberia is in a state of economic depression, and the comparison of the economic inactivity of local authorities with the active energy of China and the persistent influx of Chinese into the Baikal region (to replace the outflow of the Russian population) does not sound in our favor.

Let's return to the problems of Baikal pollution.

Selenga, the largest tributary of the lake, carries silt and industrial effluents from enterprises and settlements located along its course, starting from Mongolia. Ulan-Ude discharges industrial waste into the river in the amount of 200 thousand $\mathrm{m} 3$ per day, a third does not pass treatment facilities.

Recall that the southern part of Baikal receives about 250 thousand tons of atmospheric pollution from the Selenginsky pulp and cardboard mill, Gusinoozerskaya GRES, the cities of Irkutsk, Ulan-Ude, from Mongolia [14].

The zone of controlled limited impact on the nature of Lake Baikal is considered to be a $200 \mathrm{~km}$ wide area to the west and northwest of the lake.

Visitors should be familiar with the Baikal Guest Code and consciously adhere to moral and ethical rules. Probably, control and punishment should be implemented - expulsion and further non-admission, as on flights. A civilized person should take these measures as natural.

The sacralization of Lake Baikal as a unique natural phenomenon, which has both economic significance and requires careful attitude, should not be an obstacle for the normal self-awareness of cultural, civilized people on the lake.

Why not establish a Ministry for the Protection of Lake Baikal?

\section{Conclusions}

1. Baikal and the Baikal natural territory are in danger of ecological destruction due to technological and anthropogenic influences. Baikal is the only lake on the planet with $20 \%$ of the world's pure fresh water resource.

2. At the same time, this region plays a significant role as the epicenter of the socioeconomic revival of Siberia, which must be integrated into the general national economic system of Russia and protected from expansion from neighboring countries.

3. The main danger to Baikal today is pollution. Its sources: the remaining toxic waste from the Baikal Pulp and Paper Mill and the ongoing operation of industrial facilities concentrated in the southern part of the lake; unregulated influx of the population (tourists, entrepreneurs) directly to the shores of Lake Baikal - settlements, sanatoriums, camping sites do not have treatment facilities of the necessary capacity to prevent the discharge of sewage into the lake [15]. 
4. The lack of a reliable economic base to ensure employment of the population of the Baikal region imposes responsibility on the central authorities and local administration for the socio-economic integration of Eastern Siberia into the country's economic system. It is necessary to develop an interstate agreement with China to establish the status of Chinese migration and forms of economic cooperation in the Baikal zone.

5. The main criterion and filter for all measures to restore and preserve the natural balance of the lake should be the concept of METABOLISM, which consists in constant compensation for damage caused to nature, in a careful attitude to the unique planetary scale phenomenon, which is Baikal and nature surrounding it.

6. The revision of the existing recreational facilities on the shores of the lake allows concluding that from an architectural and urban planning point of view, their condition, with rare exceptions, requires serious reconstruction both in the planning of complexes and the civilization of architectural solutions, and in providing them with effective means of repaying damage caused to ecology of the region and the sanitary state of the lake.

7. Baikal inevitably remains and must adapt to the programs of active inclusion of Siberia in the national system of industrialization of the economy and the organization of a civilized tourist business. Let Baikal become a school for the upbringing of a person who cares about the land that bears and feeds him.

\section{References}

1. L. Podobedova, The authorities have changed the waste liquidator of the Baikal PPM for the fourth time (RBC: Business, 2020)

2. Tourism in the era of a pandemic: Baikal as a point of attraction for domestic travel, IrkutskMedia.ru, 2020. - URL: https://irkutskmedia.ru/news/1040871/?from=50 (reference date 19.03.2021);

3. D.D. Tsyrenov, On the necessity of the project "Baikal - the capital of the knowledge economy of Siberia and the Far East", Intellectual and resource potential of the regions: activation and increase in the efficiency of use. Materials of the V All-Russian Scientific and Practical Conference, 2019. p. 514-519 (2019)

4. N.B. Botoeva, Comprehensive socio-ecological and economic assessment of the state of the Baikal natural territory: problems and prospects for the development of agriculture and rural areas. Collection of papers of the VIII International Scientific and Practical Conference. 2019 Saratov: Saratov State Vavilov Agrarian University, (2019)

5. I.Yu. Khovavko, State Administration. Electronic bulletin. Moscow: LLC "Publishing house "World of Science" 69, 358-380 (2018)

6. A.V. Goncharova, N.S. Baturina, V.V. Maryinskyc, A.K. Kausd, S.R. Chalov, Journal of Great Lakes Research 46, 1, 53-61 (2020)

7. D. Karpitskaya, Who is killing Baikal - Chinese tourists or Russian indifference? Komsomolskaya Pravda (2020) URL: https://www.kp.ru/daily/27093/4166301/ (reference date 20.03.2021)

8. O.A. Timoshkin, M.V. Moore, N.N. Kulikova, et al., Journal of Great Lakes Research 44, 2, 230-244 (2018)

9. K. Kurokawa, From Metabolism to Symbiosis (L.: Academy EDITTIONS, 1992)

10. L. Zhongjie, Kenzo Tange and the metabolist movement (Routledge, 2010)

11. G.I. Galaziy, Baikal (LLC Forward, Irkutsk, 2012) 
12. A.D. Abalakov, V.K. Arguchintsev, A.V. Arguchintseva, Ecological Atlas of the Lake Baikal Basin (Irkutsk: V.B. Sochava Institute of Geography, Siberian Branch of the Russian Academy of Sciences, 2015)

13. E. Priemskaya, Spill water: why China calls Baikal its "northern sea" (Izvestia, 2019) URL: https://iz.ru/847637/evgeniia-priemskaia/razlei-voda-pochemu-v-knr-nazyvaiutbaikal-svoim-severnym-morem (reference date 21.03.2021);

14. V.I. Zorkaltsev, A.N. Kuznetsova, N.M. Sysoeva, "ECO”. Novosibirsk: ANO "Editorial office of the "ECO" journal 4, 159-175 (2018)

15. M.M. Pukemo, Journal "Water purification. Water treatment". Moscow: LLC "Publishing House “Orion”, 6 (114), 36-41 (2017) 